“Transfer” XIV: 1-2 (2019), pp. 73-99. ISSN: 1886-554

\title{
JOSÉ EMILIO PACHECO AND RECIPROCITY BETWEEN LITERARY CULTURES: GIFT THEORY AS TRANSLATION STUDIES METHODOLOGY
}

Isabel Gómez (ORCID 0000-0002-9181-4709)

University of Massachusetts Boston (U.S.A.)

Reception date: 02/02/2018; Acceptance date: 15/03/2018

In this article, I use theories of gift exchange to develop a method for translation studies that rejects the conception of translation as unidirectional. I ground my approach to gift theory in the early formulations by Marcel Mauss as read through recent reactivations by Peter Sloterdijk. Their notion of the gift differs from the concept Jacques Derrida develops, which prioritizes its voluntariness and posits that a true gift does not enter into any requirement for return. Instead, in the classic formulation by Mauss, the gift is a sacred paradox: a part of the soul of the giver that must be returned in a counter-gift both voluntary and obligatory. I contend that this paradox makes gift theory a fertile heuristic for understanding literary translation. To exemplify the potential of this method, and to ground it in the particular context of Latin American translation, I develop a case study around the translation practices of Mexican poet José Emilio Pacheco (1939-2014), who crafts an idiosyncratic and personal canon through what he calls "approximations" rather than translations. In this corpus, Pacheco translates poems by some of his own translators in a direct exchange. With another translator, his counter-gift represents an enactment of the power imbalance between English and Spanish-language poets. Gift theory allows me to interrogate Pacheco's interpersonal translation networks and what 
“Transfer” XIV: 1-2 (2019), pp. 73-99. ISSN: 1886-554

they offer toward defining a model of reciprocity within intercultural literary exchanges.

Through his translations, Pacheco performs different responses and reactions to his translators into English and to other American poets who write about Mexican history and landscape. As a translator, Pacheco tends to actively rewrite or "approximate" a poem in Spanish based on what he reads in his source texts. He makes active choices as a translator, including meaningful selection, editing, re-lineation, or even adding material as form of "literary interest" that compounds the value of a work. I interpret these actions as the effort needed to make the translation a worthy return or "counter-gift," one that will reciprocate in kind the gift the translator received from the author of the source text. Furthermore, these choices represent the necessary expression of the voluntariness, the freedom of will accorded to translators. This freedom of counter-gifting I exemplify with his translations of Archibald MacLeish and Alastair Reid. In an example of a counter-gift that displays the denial of freedom, he responds with an original poem expressing resistance at the attentions requested, or demanded, from another translator George B. Moore. While still participating in the cycle of exchange, this countergift expresses a form of rage at the involuntariness of his response.

As this case study demonstrates, gift theory provides a useful methodology for translation analysis because it rejects the assumption that translation is unidirectional, while at the same time recognizing the need to hold translation accountable to power. In other words, using the heuristic of reciprocity - a structure developed in which reciprocal, in-kind gift giving is the aim which nevertheless is not always met- when analyzing translations, we are able to still see the imperialistic gaze operating in those translations provoking the rage response, but we can also center the translations that do counter-gift, that hold up the voluntary yet also compulsory obligation to give something back. Translation studies tend toward a 
“Transfer” XIV: 1-2 (2019), pp. 73-99. ISSN: 1886-554

unidirectional mode of analysis. Research centered on Latin American theories of translation, conversely, reveals practices that pursue a more ethical vision than this one-directional extraction model and translators who position their works as a part of reciprocal cultural exchanges.

In what follows, I outline the ideas of French ethnographer Marcel Mauss and the recent reinterpretation by German philosopher Peter Sloterdjik on the concept of gifts as exchanges that must be understood as both voluntary and involuntary to perceive the ethical stakes of mutually fulfilling a basic human need to give. In their formulation, giving is always already taking back, and while the ideal gift (or, always already counter-gift) in this structure is worthy, in kind, timely, and appropriate, the structure exists because this ideal is challenging to meet. Sloterdijk positions rage and revenge as reciprocal "gifts," given in response to either the lack or inappropriateness of a counter-gift based on the previous exchange.

In Essai sur le Don, ${ }^{1}$ Mauss defines the system of gift exchange as only operating under the assumption of reciprocity. Gifts that cannot be reciprocated become debts, even to the degree of enslaving the recipient to the giver; the non-equivalence of gifts and countergifts is a further condition, as gifts must be reciprocated with interest (Mauss 1990: 42). While he develops these terms based on indigenous cultures of the Pacific Northwest including the Kwakiutl, the Haïda, and the Tsimshian, for Mauss, the gift exchange system represents a fundamental social structure (Mauss 1990: 83). He is ultimately interested in the conventions that continue to govern the ethical and social imperative to reciprocate gifts. Paradoxically compulsory and voluntary, the gift creates enduring and extended obligations for both

${ }^{1}$ Written in 1925, this foundational text was revised and published in French in 1950 and translated to English in 1954. 
“Transfer” XIV: 1-2 (2019), pp. 73-99. ISSN: 1886-554

giver and receiver. This structure applies to contemporary life, even in societies that have also created capitalist markets in which obligations end with the initial exchange of goods or services for capital.

In his observations of Maori culture, Mauss emphasizes the gift as an object invested with the soul of the giver: "to make a gift of something to someone is to make a present of some part of oneself" (Mauss 1990: 12). ${ }^{2}$ Using metaphors similar to those Pacheco applies to translation, he defines the gift as an object with agency that cannot simply be kept: to keep a part of another person, another clan would be dangerous. Instead, the gift seeks to return to "native soil" or to produce "an equivalent to replace it" (Mauss 1990: 13). When defining translation, Pacheco positions himself, and in fact all poets, as in debt to other poets from other places and times, and his translations express his appreciation. ${ }^{3}$ Furthermore, he imagines that translators perform work that saves any culture from the risk of isolation, translators are "personas que nos salvan de vivir incomunicados como peces en un acuario y cumplen la función indispensable de abrir ventanas y de tender puentes hacia lo que de otro modo permanecería desconocido" (Pacheco 1984: 7). Mauss also defines the gift as a piece of the giver's soul, one that will complete the cyclical movement of gifting and counter-gifting with or without the participation of the human actors involved. Translators -including Pacheco- express

\footnotetext{
2 "[T]he thing itself possesses a soul [...] To retain that thing would be dangerous and mortal [...] Finally, the thing given is not inactive. Invested with life [...] it seeks to return to what Hertz called its 'place of origin' or to produce, on behalf of the clan and the native soil from which it sprang, an equivalent to replace it" (Mauss 1990: 12-13).

${ }^{3}$ Introducing the "aproximaciones" included in his collected poems: "[N]adie trabaja aislado: debe tanto a los poetas que lo procedieron como a sus contemporáneos y a los que vienen después. Son muchos aquellos y aquellas de quienes he aprendido y continúo aprendiendo. Me duele no expresarles mi agradecimiento en esta página" (Pacheco 1980: 11).
} 
“Transfer” XIV: 1-2 (2019), pp. 73-99. ISSN: 1886-554

similar convictions about the agency of texts themselves in their pursuit of reciprocity, as in Pacheco's claim that the Spanish language itself presents these gifts: "el verdadero autor de estas Aproximaciones es el idioma español. La prodigiosa flexibilidad y las infinitas posibilidades del castellano quedan demostradas en su poder de convertir en versos que hablan "como nacidos en él y naturales' la obra de tantos poetas, tiempos y culturas" (Pacheco 1984: 8). Yet this exchange can never be completed, accounts can never be balanced, because the counter-gift will set up another debt, and the portions of soul exchanged can never be fully returned. ${ }^{4}$ The gift itself, an active and living part of the soul of the giver, communicates a desire for return. While Pacheco, and Benjamin before him, figure translation as expressing the will of the text or even the language itself, there remains an interesting fissure in this application of gift metaphor to the act of literary translation. The translation emerges as a gift in which the roles of giver and recipient are even more thoroughly merged within one action; both translator and translated author give and receive.

In my interest in turning ideas about literary influence, intertextuality, and exchange toward concepts of reciprocity and away from competition, I draw from the arguments Sloterdijk makes for a return to Mauss to correct the way he has been read within the traditional Freudian model of the psyche. For Sloterdijk, psychoanalysis overemphasized eros in which the human constantly seeks to fulfill a lack. He proposes that a greater emphasis on thymos would

\footnotetext{
${ }^{4}$ A similar concept can also be seen in Walter Benjamin's "Task of the Translator." Much like Mauss and his vision of the gift, Benjamin centers on the literary texts themselves: "the translatability of linguistic creations ought to be considered even if men should prove unable to translate them" (Benjamin 2000: 16). While Pacheco may not share the messianic belief in translation that Benjamin explores, this sense of the agency of the text itself is shared.
} 
“Transfer” XIV: 1-2 (2019), pp. 73-99. ISSN: 1886-554

allow more focus on a human drive to give away rather than take. ${ }^{5} \mathrm{I}$ argue that translation can be an experience with literary influence operating as an expression of thymotic spirit rather than just as, eros, agon or resentment. In fact, as Pacheco expresses above, the thymotic impulse is present for many literary translators, and translation expresses a desire to give, to give both freely and as repayment of a cultural debt. ${ }^{6}$

Sloterdijk calls Mauss "a tragic case" because he has been misread as speaking exclusively to the field of ethnography rather than ethics (Sloterdijk 2014: 10). Furthermore, he does not want to revisit Mauss in the same vein as Derrida. In much of his work, Derrida was concerned with "the possibility of a giving that is not also a taking back" (Derrida 1991: 253), with the paradox of a gift that is outside of relations of exchange. My argument also supplements Harold Bloom's understanding of literary influence through an erotic economy in which desire is based in lack and governed by agon, or the spirit of competition. Bloom associates the term "influence" with giving away something which should not be given away: the self, the personality. ${ }^{7}$ Mauss, as Sloterdijk understands him, offers the alternative understanding of the gift of the self through influence: instead of agon, it can be thymos, an expression of strength and recognition.

\footnotetext{
5 "The erotic economy is not just driven by money but by lack. [...] If there is no lack, it invents it in order to go on. The thymotic economy describes human beings as creatures who want to give instead of take" (Sloterdijk 2014: 17).

${ }^{6}$ Even when, or especially when, they are also being paid for their work -i.e. the thymotic impulse and the payment for translation as labor are not necessarily connected- or rather they are necessarily not connected, in the sense that translation as labor must be compensated but translation as gift must be given and received as voluntary.

${ }^{7}$ Influence, at least in the case of a "weaker" poet, dooms a poet to produce merely derivative work because he "lacked strength to overcome his anxiety of influence" (Bloom 1997: 6).
} 
“Transfer” XIV: 1-2 (2019), pp. 73-99. ISSN: 1886-554

Additionally, Sloterdijk understands gift theory as relevant to the economy of the modern state, asserting that taxes ought to be understood as gifts, not debts (Sloterdijk 2014: 10). This reframing would bring about a different relationship between the individual and society in which there would be a focus on generosity rather than lack, despite the paradox that these "gifts" would be both voluntary and obligatory. ${ }^{8}$ In applying Sloterdijk's reevaluation of Mauss to literary translation, I am also addressing the perspective that all translation is imperialistic at root. Looking at translation acts as an expression of thymotic spirit that participate in reciprocal gift exchanges between individuals, languages, and cultures brings out aspects of translation that are not always already appropriating or aligned with hegemonic power or the control of imperialism.

However, generosity is not the only expression of this thymotic desire. While the "stout-hearted" or "prideful" side of thymos is activated through acts of generosity, there is also the "rage" side, when thymos, or the desire for recognition, is denied. Sloterdijk describes the raging thymotic individual as the receiver of pain who has not been able to "give" anything of his suffering back. Sloterdijk describes "the giving dimension of rage" (Sloterdijk 2010: 56), claiming that enraged revenge-seekers operate not out of material or spiritual lack, nor out of a desire to take from others who have more. Instead, they are motivated by a need to give suffering to those who have denied them recognition. ${ }^{9}$ Before Sloterdijk, Roberto Schwarz

\footnotetext{
8 "Mauss is the first and only thinker to date who understood that in the gift, the principle of voluntariness does not cancel out the principle of necessity or obligation. In other words, the gift, like Christ, has a double nature, i.e., it includes both an element of voluntariness and an element of coercion" (Sloterdijk 2014: 10).

9 "There cannot be any doubt that there is a link between rage and pride, thanks to which rage provides itself with a moral certainty of its own legitimacy. The higher the
} 
“Transfer” XIV: 1-2 (2019), pp. 73-99. ISSN: 1886-554

already theorized a similar relationship between gift-giving, pride, and rage within the Brazilian social milieu. Paying someone an unreturnable "favor" (to use Schwarz's term) turns what appears to be generosity between individuals into what Sloterdijk describes as "rage" or "revenge" that will arise within someone who has been denied the chance to give anyone anything reciprocally, not even suffering. Schwarz writes about the sometimes perverse and manipulative nature of "favor" specifically to understand Brazilian social life as a heritage of the uneasy adoption of ideologies of liberal political equality in the nineteenth century while slavery was still actively supporting the national economy. Describing a society peopled by landowners, "free men," and slaves, Schwarz articulates the relationship between the first two types as governed by the bestowal of unreturnable favors, an inescapable and unmentionable social pact. In this system, acts of favor from landowners to "free men" serve them both as an "ever-renewed complicity [... that] assured both parties, especially the weaker one, that neither was a slave" (Schwarz 1992: 40). Sloterdijk describes a similar moment, where revenge responds to the unmet desire to be able to reciprocate, the rage born of inequality between those who are living in the same household or in the same society, as Schwarz describes with Brazil.

I am interested in what becomes visible in literary translation when we frame literary influence within Sloterdijk's thymotic economy, in which desire is based on strength of the individual within a group and a concomitant desire for recognition. Where there is freedom and mutual recognition, translation gifts can be reciprocally exchanged; when a translation is presented as a "favor" in the Schwarzian manner, it may provoke a different response: one of rage.

factor of pride in rage, the more effectively will the 'you may' be transformed into a 'you should'” (Sloterdijk 2010: 56). 
“Transfer” XIV: 1-2 (2019), pp. 73-99. ISSN: 1886-554

Given this framework, José Emilio Pacheco emerges as a translator who expresses both the rage and the reciprocal sides of thymos through his different reactions to English-language translators. In his translations of poems by translators of Mexican poetry, he demonstrates a generous spirit of participating in a gift exchange of equals. But in one example, his counter-gift comes in the form of a poem that rejects the implication of another translator's invitation to give an interview because it represents a forced performance in relation to the USA literary market.

In his translation gifts, Pacheco expresses both generous reciprocity and reciprocity taken to the point of rage. In my analysis of his interactions with translators from Spanish to English, he figures literary translations as producing a site of gift exchange, as paradoxical gifts that are both voluntary and compulsory, and as immaterial gifts which can be both given and kept at the same time. The "thymos" or "stout-heartedness" involves demonstrating the ability of the translation and the target culture to "match" or "give worthily to" to the author or the source culture. While Pacheco translated widely from world poetry, my case study focuses on his poetic responses to some of his own translators into English and his responses to others who established new connections between the Spanish and English languages in an American Hemispheric vein. These cases allow me to highlight a dynamic of exchange that can take on both extremes of the gift exchange spectrum: the expression of pride and worthiness in a fitting counter-gift as well as the expression of rage or "agon" in the returning of a gesture that comes with power, demand, and overstepping of bounds.

Ronald J. Friis, Mary Docter, and Hugo Verani all study the central importance of intertextuality to the poetry of Pacheco, particularly after his third book of poetry No me preguntes cómo pasa 
“Transfer” XIV: 1-2 (2019), pp. 73-99. ISSN: 1886-554

el tiempo (1969). Yet his translations are seldom incorporated into this analysis, nor have they been fully evaluated as creative work. ${ }^{10}$ Pacheco calls them "approximations" rather than "translations," a key choice that avoids identifying with the attendant history of the "translatio studii" as something that accompanied the "translatio imperii" or "transfer of rule." Instead, he posits an alternative vision of translation as "drawing near," a practice he describes as both "barbaric" and "cultured," acknowledging the multidirectional palimpsest of his translations. ${ }^{11}$ The term "approximation" that he uses foregrounds the tensions in the act of translation, using a verb that signifies both "drawing near" but also always "holding apart." "To approximate" will never mean either "to duplicate" or "to bring over:" an approximation never quite gets there. This term also relates to his concept of poetry as the result of the collective practice of poetic work. When introducing his anthology Aproximaciones he writes: "[S]i por mí fuera preferiría mil veces que estas páginas colectivas se publicaran anónimas" ["Were it up to me, I'd prefer a thousand times that these collective pages be published anonymously"] (Pacheco 1984: 7; my translation). A heteronym is an invented personality who writes poetry that may differ from the works signed by the poet's own name. ${ }^{12}$ Pacheco created two heteronyms who, like him, write in

\footnotetext{
${ }^{10}$ While Friis mentions the value of Pacheco's translations, he stops short of analyzing them (Friis 2001: 59-60; 105).

${ }_{11}$ "En 1934 [Borges] había escrito los Two English Poems que nunca ha querido traducir al español. En la cuenta de la barbarie y la falta de respeto que coexisten en este libro con sus rasgos más culturales, hay que poner la afrenta y osadía de traducir al castellano a un clásico de nuestra lengua. Valga como atenuante el hecho de que la tentativa se ha extendido a lo largo de casi veinticinco años" (Pacheco 1984: 171).

${ }_{12}$ Portuguese poet Fernando Pessoa (1888-1935) championed this practice and crafted numerous heteronyms.
} 
“Transfer” XIV: 1-2 (2019), pp. 73-99. ISSN: 1886-554

Spanish: Julián Hernández and Fernando Tejada. ${ }^{13}$ Just as his heteronyms require an informed reader to identify them as such and understand the game of inventing new poetic voices, his translations need to be considered as masks and displaced performances of his ideas about authorship as anonymous and collective.

In the voice of one of his heteronyms Julián Hernández, Pacheco writes, or in fact translates, an aphorism by the FrenchUruguayan poet known as the Comte de Lautréamont, pseudonym of Isidore-Lucien Ducasse: "La poesía no es de nadie: se hace entre todos" (Pacheco 1980: 246), affirming that literary world-making cannot be an individual enterprise. Pacheco's translations perform this idea: that poetry is made by the trans-historical, trans-linguistic, and often anonymous effort of writers in every language, where the individual is subordinate to the text. He includes translations in most of his chapbooks and in the first two editions of his collected works Tarde o temprano (1980 and 1986) and publishes a volume entirely comprised of translations, his 1984 collection Aproximaciones. Drawn from wide and varied corpus of source texts: from anonymous Greek epigrams, Japanese haiku, and works by indigenous poets throughout the Western hemisphere; widely influential poems by Petrarch, Guillaume Apollinaire, Gérard de Nerval, Rainer Maria Rilke; U.S. voices including T.S. Eliot, Marianne Moore, and Elizabeth Bishop; and Brazilian modernists Vinicius de Moraes and Ledo Ivo, Pacheco's approximations blend high with low, expansive lyric with fragmentary anti-poetry. Studied within the framework of Mexican and SpanishAmerican networks of translation practice, his work is compared to

${ }^{13}$ The polyvocal nature of his work as related to his translation practice is supported by the fact that he also invents three other heteronyms, alternative poetic personas with invented biographies: Gordon Woolf, Piero Quercia, and Azevedo Oliveira. Pacheco claims to translate their works from English, Italian, and Portuguese, and includes them in Aproximaciones as though they are translations from existing authors. 
“Transfer” XIV: 1-2 (2019), pp. 73-99. ISSN: 1886-554

that of Octavio Paz (Frances Aparicio 1991; Hugo Verani 1998) who he claims as an influential mentor. Mary Docter positions his "approximations" within what she calls his "poetics of citation," in which his original poetry is frequently a pastiche of earlier texts. His re-translations of works already rendered into Spanish invite comparative study (Isibasi Pouchin: 2015). In the case of his translation of "El desdichado" by Gerard de Nerval, Susana Zanetti traces the way he both responds to prior translations by $\mathrm{Paz}$ and Xavier Villarutía and inspires a slew of subsequent versions by many of the major poets of his day, including Homero Aridjis, Juan José Arreola, Tomás de Segovia, Salvador Elizondo, Gabriel Zaid, and José de la Colina (Zanetti 2010: n.p.). His translations of T.S. Eliot, as I argue elsewhere, represent a similar response to other available Spanish versions, in which he chooses to draw closer to the metric qualities of the source text but pushes the lexical variety further away, choosing particular Spanish vocabularies that evoke a particularly Mexican orality or environment to exploit moments in which his translation can expand the Western landscapes of the USA imaginary to include Mexico. My intention here is to focus on the reciprocity involved in the gesture of translating work by lesserknown poets who are also translators of Mexican poetry into English, including but not limited to his own translators.

One translation practice that sets Pacheco apart from these other members of his generation: in addition to the homage to and cannibalization of these poets of universal renown, he translates selected original poems by three poets who translated him: Edward Dorn, Alastair Reid, ${ }^{14}$ and George McWhirter..$^{15}$ He translates works by

\footnotetext{
${ }^{14}$ In Tarde o temprano, Pacheco translates two selections by Edward Dorn, "Tesis," and "El pulpo piensa con su tercer brazo" and three by Alastair Reid, "La sintaxis de las estaciones," "Ejemplo," and "Al hablar una lengua extranjera" (Pacheco 1980: 250-2;
} 
“Transfer” XIV: 1-2 (2019), pp. 73-99. ISSN: 1886-554

other poet-translators who worked with Latin American and especially Mexican poetry including Pulitzer prizewinner Archibald MacLeish, ${ }^{16}$ Michael Schmidt, Tom Raworth, Charles Tomlinson, and Kenneth Rexroth. ${ }^{17}$ These translations reciprocate their attentions and also sample from the English language poetry of that network of translators bridging the gap between the languages of the Americas and between the Spanish and Spanish-American avant-garde and protest poems of the first half of the twentieth century with the anti-poetry of the second half. ${ }^{18}$ Some selections share Pacheco's own poetic interests, including medieval bestiary, the colonial and baroque

254-6). With Gordon Brotherston, Dorn translated one of Pacheco's earliest poems, "Árbol entre dos muros" in a chapbook Tree Between Two Walls (Black Sparrow Press: 1969). Reid translated the entire collection Don't Ask Me How the Time Goes By (1978).

${ }^{15}$ In Aproximaciones he includes two poems by McWhirter, "The Iguana" and "Reparto Agrario" labeled "Dos poemas mexicanos" (Pacheco 1984: 116-7). McWhirter was one of the editors and translators for Pacheco's Selected Poems (1987), but a number of the selections had been previously published in other anthologies or magazines.

${ }^{16}$ In Aproximaciones he includes three selections labeled "Del Preámbulo de Bernal Díaz del Castillo a su libro: Dos fragmentos épicos de Conquistador y un poema lírico.” These selections are titled "Se volvieron palabras nuestras hazañas"; "El descubrimiento de México," and “Tú, Andrew Marvel” (Pacheco 1984: 60-70).

${ }^{17}$ In Tarde o temprano he includes: "Escorpión" by Michael Schmidt; "Los otros" by Tom Raworth; "Teoría de la regresión" by Charles Tomlinson; and "Ciervos" and "Leones" by Rexroth (Pacheco 1980: 248-50; 253; 257-8). Schmidt translated Aztec poetry in Flower and Song (1983); Raworth translated Vicente Huidobro; Tomlinson translated Cesar Vallejo, Antonio Machado, and Octavio Paz, with whom he collaborated on a bilingual sonnet sequence Airborn / Hijos del aire (1983); and Rexroth translated works by the "Generación de 27" for 30 Spanish Poems of Love and Exile (1956).

${ }^{18}$ One central figure in this network absent from Pacheco's translations is Lawrence Ferlinghetti, who never translated from Spanish, to my knowledge. He did support Latin American poetry as an editor at City Lights, where he published the first English translations of Nicanor Parra's Anti-Poems (1960) in the same Pocket Poets series as Alan Ginsburg's Howl. Pacheco also never translated anything by Gordon Brotherston, another of his first translators. Brotherston never published poetry, just scholarship on the poetry of indigenous peoples of the Americas and of Latin American poets. 
“Transfer” XIV: 1-2 (2019), pp. 73-99. ISSN: 1886-554

literary archives, time and the concept of the eternal return, metapoetry, urban poetry, and anti-poetry. For example, Pacheco writes many animal poems, often expressing a connection with the extrahuman. From Rexroth, he translates "Crows" and "Lions;" from Schmidt "The Scorpion;" and from Dorn "The Octopus Thinks with his Arms"-Pacheco even has a poem of his own titled "El pulpo." Other translations are of poems that express a connection with the Spanish language or Mexican history. From Reid he translates "Speaking a Foreign Language" in which the speaker expresses gratitude for those who tolerate his Spanish as well as the generosity he feels towards his friends who are not native English speakers (Reid 1978: 91). With McWhirter he translates two of his poems from a series written in and about Mexico, and the case I will focus on, Pacheco translates sections of Conquistador (1932) by Archibald MacLeish, an epic poem that rewrites the "True History of the Conquest of New Spain" (1576) by Spanish soldier Bernal Díaz del Castillo.

While Pacheco reciprocates some gifts received from his translators, he does not always accept their attentions as benign or generous. In the case of George B. Moore, another poet-translator who published selected translations from Pacheco, the return gift comes not in the form of a translation but rather as an original poem in which he rather harshly rebuffs Moore's interest in inviting the poet to visit the University of Colorado at Boulder in order to give a reading and conduct an interview, presumably to be published later. The phone call and telegram he received from Moore did exist, as Elena Poniatowska and Friis (Poniatowska 1993: 29-30; Friis 2001: 181) confirm. ${ }^{19}$ The poem resulting from this encounter titled "Una

\footnotetext{
19 Whereas they study this poem in relationship to Pacheco's poetics of humility, "ninguneo" or nobody-ness (Friis 2001) or his intertextuality with other contemporary poets (Poniatowska 1993), my interest centers on the fact that Moore is also a
} 
“Transfer” XIV: 1-2 (2019), pp. 73-99. ISSN: 1886-554

defensa del anonimato" (Carta a George B. Moore para negarle una entrevista)" ["In defense of anonymity (Letter to George B. Moore, denying him an interview)"] first appeared in Los trabajos del mar (1983), the first poetry collection he published after the first edition of his collected works Tarde o temprano (1980). From the translation by Linda Scheer:

you phone me from Estes Park, Colorado.

You say you've read everything in the bottle

(across the seas: our two languages).

And you want to interview me.

How can I explain that I've never given

an interview,

that my wish is to be read, not "famous,"

that what is important is the text and not its author, that I don't believe in the literary circus?

(Pacheco 1987: 175)

Pacheco's speaker appears here to reject first the mere concept of the interview as a part of the mobilizing of authors as celebrities rather than allowing texts to speak for themselves. His poem goes on to indicate the continued interest of the translator, the continued attentions in the form of a follow-up invitation in the form of a telegram, a gesture he receives as ostentatiously expensive, almost profligate in its show of resources and access:

translator of Pacheco, and as such, the poem relates to Pacheco's translation poetics as well. Poniatowska describes Pacheco's reaction when Moore sent him "un telegrama de diez páginas con cerca de cien preguntas. Le dio pena rechazar así nada más la entrevista y le contestó con ‘Una defensa del anonimato'” (Poniatowska 1993: 30). 
“Transfer” XIV: 1-2 (2019), pp. 73-99. ISSN: 1886-554

Then I receive a long telegram

(how much must have been spent to send it).

I can't answer and I can't not answer.

And these lines come to me. It's not a poem

It doesn't aspire to the privilege of poetry

(it's involuntary).

(Pacheco 1987: 175)

These two lines encapsulate the paradox of the poem as a response: "I can't answer and I can't not answer" and "it's involuntary" - these two characterizations of the work make Pacheco's poem a form of counter-gift: it is demanded, obligatory, but given with an expression of rage rather than generosity.

Moore published two translations "Ghosts" and "Ratus Norvegicus" in the Mississippi Review in 1983, and they tend toward adherence to word-for-word rendering of grammatical equivalence. For example, the first lines of "Ghosts" read: "I have never seen ghosts. I carried one / for entire years in the dismantled / theater of the memory" (Pacheco 1983: 70). This is Moore's version of "Nunca he visto fantasmas. Llevé una / años enteros en el desmantelado / teatro de la memoria" (Pacheco 2009: 215). The phrase "theater of the memory" maintains the article unnecessarily; the choice of "dismantled" does not have the same collocation in English of a stage that has been struck, after the show is over. Where he makes changes, he reduces the diversity of terms for the ghosts in Pacheco's source: "espectros, fantasmas" begin the poem, and it only turns to use the more neutral word "apariciones" once the haunting has ceased in the final line: "Un día cesaron las apariciones" (Pacheco 2009: 215). In Moore's translation, the word "ghosts" is singularly used, until the final line: "One day the apparition was gone" (Pacheco 1983: 70).

The same tendencies appear in "Ratus Norvegicus" where the first lines include a series of choices that emphasize word-for-word translation over sense and sound. 
“Transfer” XIV: 1-2 (2019), pp. 73-99. ISSN: 1886-554

\begin{abstract}
Dichosa con el miedo que provoca, la rata parda de Noruega (nacida en Tacubaya y plural habitante de barrios más bien pobres), en vez de ocultarse observa con ojillos iracundos
\end{abstract}

(Pacheco 2009: 230-1)

Moore's translation reads as follows:

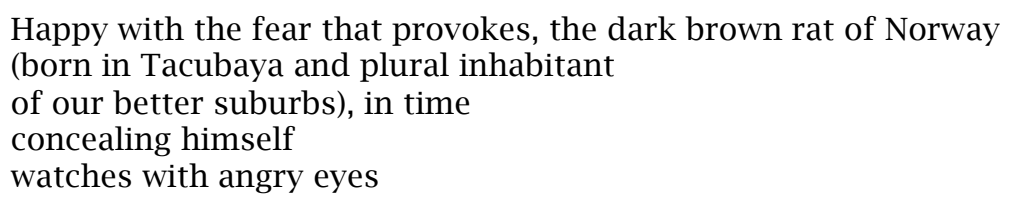

(Pacheco 1983: 71)

Not only is the translation "Happy with the fear that provokes" an over-adherence to word order, the translation of "en vez de ocultarse / observa" as "in time / concealing himself / watches" reverses the sense of the poem, it should be "instead of" to convey the image of a bold-faced, angry-eyed rat who doesn't bother to hide himself. More than errors, these elements in the translations by Moore indicate a failure to make the poem his own. In his response, Pacheco writes that his readers are collaborating with him: "In reality the poems you've read are yours: / You, their author, who invent them as you read." (Pacheco 1987: 179). According to my reading, Moore has not fully given the gift of his own invention through his translations.

The other poet-translators who work on Pacheco tend toward a greater "stout-heartedness" to alter the work in order to make it a stand-alone poem in English, a greater approximation both to Pacheco's own poetics and to Mexico. In the example of the first English translation of “Árbol entre dos muros," one of Pacheco's 
“Transfer” XIV: 1-2 (2019), pp. 73-99. ISSN: 1886-554

earliest poems, the translators Gordon Brotherston and Ed Dorn make some changes in vocabulary and lineation, which Pacheco later takes back into Spanish, altering the poem significantly in subsequent editions of his collected works. Additionally, these other translators all traveled to Mexico rather than issuing invitations from the USA for Pacheco to visit them there. George McWhirter translated Octavio Paz's Blanco (an unpublished version completed before the translation currently in wide circulation done by Eliot Weinberger in 1987) and also spent a year in Mexico where he wrote a series of "Mexican Poems" (Pacheco 1984: 185).

In the case of his translation from Archibald MacLeish, the selection Pacheco translates from the Pulitzer prize-winning epic poem Conquistador (1932) constitutes a gesture to pay a debt, to return the gift made by the author to Mexican cultural heritage as a whole. Describing MacLeish in his note about the author, he writes:

México está en deuda con el poeta que le declaró su amor hace medio siglo y escribió un poema épico [...] en que habla Díaz del Castillo [...] No fue su única relación con nuestro país: promovió la obra de los muralistas en los Estados Unidos y cuando destruyeron lo que pintó Diego Rivera en el Centro Rockefeller de Nueva York escribió una serie de poemas de protesta: Frescoes for Mr. Rockefeller's City. (Pacheco 1984: 165).

Pacheco goes on to express his sense of unfairness at the virulence of the attacks from his peers and friends when, from his position as the Director of the Library of Congress from 1939-1944, he critiqued as antidemocratically pessimistic some of the positions of other writers of his generation. In general, Pacheco appears to call for attention to the whole of his work, which included public poetry that bore witness to all major events of the twentieth century as well as the active protection of other poets such as Saint-John Perse, who MacLeish helped find refuge when the Nobel prizewinning poet was 
“Transfer” XIV: 1-2 (2019), pp. 73-99. ISSN: 1886-554

exiled from Europe under fascism. In addition to this sense of debt in the form of the care and attention to Mexican culture and history, the poem itself also speaks to the ethics of the text based on the personal eyewitness of the author as opposed to texts based on the written accounts of others. Archibald MacLeish followed the route of Cortés through Mexico before writing his epic poem Conquistador, the long epic poem written in terza-rima style stanzas and for which MacLeish won a Pulitzer Prize, solidifying his reputation as a poet. The translation by Pacheco enacts a return to Spanish but in verse form of the "True History of the Conquest of New Spain" written by Díaz del Castillo in 1576. This text represented the soldier Castillo's attempt to supplement and correct the chronicles of the Indies, which were being written by priests and lettered Spaniards who never left Spain. When MacLeish rewrote this text in English, he was also translating the work from an unlettered narrative style into epic verse. Pacheco's translation has the poetic speaker Diaz del Castillo also reclaim his story, in Spanish:

Soy un anciano ciego, enfermo e ignorante:

La sombra de la muerte está en mi rostro:

Sólo tengo las manos para guiarme:

Y él no es ignorante: no está enfermo: pero yo

¡Combatí en las batallas! ¡Estas son mis hazañas!

Los nombres que él declama como si fueran

Tomados de Heródoto-los muertos y sus guerras: material de lectura-

Fueron nombres de amigos: mis compañeros muertos:

(Pacheco 1984: 61-2)

I am an ignorant old sick man: blind with the

Shadow of death on my face and my hands to lead me: 
“Transfer” XIV: 1-2 (2019), pp. 73-99. ISSN: 1886-554

And he not ignorant: not sick-

but I

Fought in those battles! These were my own deeds!

These names he writes of mouthing them out as a man would Names in Herodotus-dead and their wars to read-

These were my friends: these dead my companions:

(Macleish 1932: 10)

Frequently, as in the selection cited, Pacheco's translation read alongside MacLeish appears less stilted, more natural. At times the source text reads as though it were a translation of some original which indeed, it is, given that MacLeish worked from the translation by Alfred Percival Maudsley from 1912.

The reference to Herodotus represents another recurring theme of Pacheco's. In this way, Conquistador shares several of his thematics: colonial texts, Mexican landscapes, and the Greek historian and philosopher of time and change. Additionally, Pacheco takes opportunities to introduce or interpolate details into his translation that connect MacLeish's poem with the Peninsular literary tradition:

Tan pobre como soy he sido joven en aquella tierra:

Lo que ahora son palabras fue mi vida: estas letras heladas en la página

Con borrones de tinta y el pulgar aferrado a la pluma de ganso:

Las manchas en mis dedos

Toman la forma de mi propia vida. . .

(Pacheco 1984: 62-3)

I: poor as I am: I was young in that country:

These words were my life: these letters written 
“Transfer” XIV: 1-2 (2019), pp. 73-99. ISSN: 1886-554

Cold on the page with the split ink and the shunt of the Stubborn thumb: these marks at my fingers:

These are the shape of my own life. .

(Macleish 1932: 11)

In this case, Pacheco chooses to interpolate the image of a quill pen into the scene. His choice of the phrase "pluma de ganso" borrows a common trope from Francisco de Quevedo and Luis de Góngora and expands on the image in MacLeish in which the thumb of the writer has become metonymically connected with the writing instrument in the "shunt of a stubborn thumb." The phrase in his translation expands on his source text: "el pulgar aferrado a la pluma de ganso" connects the iron will of the author with the iron sword of the soldier. It also connects the authorial voice with the longer historical trajectory of epic and lyric writing in Spanish: his "pluma" relates to that of the Spanish tradition.

Yet Pacheco does not merely interpolate details connected with the Spanish Renaissance canon. Additionally, he interpolates into his translation vocabulary from contemporary Mexico. “iQué lata!” is a phrase used among friends, expressing informal, self-reflexive critique closer to "how lame" than to the more conservative formulation "how tedious" found in the original. "iQué lata el veterano que reclama su fama!" ["The tedious veteran jealous of his fame!"] "Qué lata" as a phrase reads very contemporary and is used both in Mexico and in Spain. While I read Pacheco's translation of MacLeish primarily in the stout-hearted, generous category rather than the rage category of thymos, it should be noted that several lines, in which Bernal Díaz expressed his resentment about being narrated by a priest who did not participate in the conquest, could be read in the voice of the Mexican poet reclaiming the story of his own territory, taking back the narrative out of the mouth of another. In this way, Pacheco's 
“Transfer” XIV: 1-2 (2019), pp. 73-99. ISSN: 1886-554

translation represents a double-reclaiming, and an enactment of the cyclical nature of reciprocal translations.

In another line, Pacheco names the "nopal," a fruit-bearing cactus typical of the Mexican landscape and central in its cuisine, where the source text reads as an explanatory translation. Where MacLeish wrote "My lands deserts in Guatemala: my fig-tree the / Spiked bush: my grapes thorns" Pacheco translates "Mis tierras: los desiertos guatemaltecos: nopal / En vez de higuera: mis uvas las espinas" (Pacheco 1984: 61). While in the poem as a whole this passage fits within the larger complaint of the speaker Bernal Díaz, that the learned man of Spain has everything he lacks (gold, education, his health), it also marks the turning point between valuing what he did gain in the New World (lands, new plants, children) even if these gains all look different from what he had expected or what might be recognizable for their value in Spain.

Ultimately, even with the poem "In defense of anonymity (Letter to George B. Moore, denying him an interview)" Pacheco reciprocates and responds to the translation work of one of his contemporaries in the US American poetic sphere. He enters into conversation with Moore through his poetry even as he rejects the invitation to be interviewed personally. The poem affirms the work of speaking collectively and for the speechless, but it also delivers the corrective that a poet cannot be interviewed, only read. ${ }^{20}$ He writes:

Strange this world of ours: each day

it's interested more in poets

and less in poetry.

The poet has ceased to be the voice of his tribe,

\footnotetext{
${ }^{20}$ This poem blends the poetic speaker and the author Pacheco: the episode described in the poem actually occurred and the author repeated the views expressed in the poem in the introductions to his collected works and translations.
} 
“Transfer” XIV: 1-2 (2019), pp. 73-99. ISSN: 1886-554

he who speaks for the speechless.

He's become one more entertainer

(Pacheco 1987: 177; translation by Linda Scheer, italics in original)

The speaker in Pacheco's poem does not want to give an interview because to do so would appear to speak for his poems, which speak for themselves and for the culture that produced them. The word entertainer - which appears in English even in the source text - indicates disdain for the growing commercialism of the literary sphere, and his concern at what is lost when the writers are expected to be involved in the afterlives of their texts: both the freedom of those texts to move beyond their source languages or cultures and the freedom of readers (and translators, implicitly) to do with those texts what they will. He goes on to make this claim on behalf of both his "verses and versions" which in Spanish "mis versos y mis versiones" indicates his original lines of poetry and his versions of those written by others, his translations.

Perhaps you've read that Juan Ramón Jiménez planned to put out a magazine fifty years ago.

It was going to be called Anonymous.

He would publish texts, not names

and it would be made up of poems, not poets.

Like the Spanish master, I want

poetry to be anonymous since it's collective

(that's how my verses and versions are).

Possibly you'll say I'm right.

You who've read me and don't know me.

We'll never see each other, but we're friends.

If you liked my poems

what's the difference if they're mine / another's / no one's.

In reality the poems you've read are yours:

You, their author, who invent them as you read.

(Pacheco 1987: 179; translation by Linda Scheer). 
“Transfer” XIV: 1-2 (2019), pp. 73-99. ISSN: 1886-554

In this poem, the speaker challenges the reader to be take the same kind of responsibility as does a translator: not going back to an author to ask for more, for explanation or interpretation or biographical insight, but rather taking the gift as given and doing with it what they will.

Perhaps that was the major difference between the translators who received reciprocal translations and Moore, who received the counter-gift of rage in poetic form. Moore's translations did not reinvent Pacheco's poems in English. They were not "voluntary" enough, too inflexibly tied to their source; nor could his invitation be met with voluntary response, because of the power differential in their positions (his ability to afford an expensive telegram, his position within a wealthier university system, and the hegemonic language of English). However, Pacheco's counter-gift, as Poniatowska points out, nevertheless connected his own poetics with Moore's gesture, even in the negative sense. "El resultado es que José Emilio ha hecho depositario a Moore de uno de sus credos poéticos y humanos más conmovedores" (Poniatowska 1993: 30).

In understanding the network of Pacheco and his translators, a picture emerges of a series of gift exchanges between English and Spanish, between Mexico and the English-speaking public world, in which the balances of power remain visible, the obligations and responsibilities are perceptible, but there is nevertheless the space for voluntary will. The world literature framework has drawn criticism for centering "global English" or "translatese," a form of writing that levels aesthetic differences and subsumes diverse cultural forms into the limited norms of a global cultural marketplace. Focusing on translations that instead position themselves as involved in an exchange of gifts has implications for translation studies, in which the focus would move away from the unidirectional and toward the reciprocal. 
“Transfer” XIV: 1-2 (2019), pp. 73-99. ISSN: 1886-554

\section{WORKS CITED}

APARICIO, Frances R. (1991). Versiones, interpretaciones y creaciones: Instancias de la traducción literaria en Hispanoamérica en el siglo veinte. Gaithersburg, MD: Ediciones Hispamérica.

BENJAMIN, Walter. (2000). "The Task of the Translator". Tr. Harry Zohn. In: VENUTI, Lawrence. (ed.). The Translation Studies Reader. London \& New York: Routledge, 15-25.

BLOOM, Harold (1997). The Anxiety of Influence. A Theory of Poetry. Second Edition. New York \& Oxford: Oxford UP.

DERRIDA, Jacques (1991). "Des Tours de Babel”. Tr. Joseph F. Graham. In: KAMUF, Peggy. (ed.). The Derrida Reader. New York: Columbia UP, 244-53.

DOCTER, Mary. (2002). "José Emilio Pacheco: A Poetics of Reciprocity". Hispanic Review 70.3: 373-92.

FALK, Signi Lenea (1965). Archibald MacLeish. New York: Twayne.

FRIIS, Ronald. (2001). José Emilio Pacheco and the Poets of the Shadows. Lewisburg: Bucknell UP.

ISIBASI POUCHIN, María Elena. (2015). "La retraducción como forma de reescritura en José Emilio Pacheco. Una aproximación a sus aproximaciones". Diss. Colegio de México.

MACLEISH, Archibald. (1932). Conquistador. Boston \& New York: Houghton Mifflin.

MAUSS, Marcel. (1990). The Gift. The Form and Reason for Exchange in Archaic Societies. DOUGLAS, Mary. (ed.). Tr. W.D. Halls. New York: W. W. Norton.

PACHECO, José Emilio. (1984). Aproximaciones. FLORES, Miguel Angel (ed.). Mexico: Editorial Penélope.

(1983). "Ghosts" and "Ratus Norvegicus". Tr. George B. Moore. Mississippi Review 12.1/2: 70-72.

(1987). Selected Poems. MCWHIRTER, George (ed.). Trs. Thomas Hoeksema, George McWhirter, Alastair Reid, Linda Scheer, 
“Transfer” XIV: 1-2 (2019), pp. 73-99. ISSN: 1886-554

Edward Dorn, Gordon Brotherston, Katherine Silver \& Elizabeth Umlas. New York: New Directions.

-_. (1980). Tarde o temprano. $1^{a}$ edición. México, D.F.: Fondo de Cultura Económica.

(2009). Tarde o temprano: poemas 1958-2009. $4^{a}$ edición. CLAVEL, Ana (ed.). México, D.F.: Fondo de Cultura Económica.

PONIATOWSKA, Elena. (1993). "José Emilio Pacheco: naufragio en el desierto". In: VERANI, Hugo J. (ed.). La hoguera y el viento: José Emilio Pacheco ante la crítica. Mexico D.F.: Ediciones Era, 1834 .

REID, Alastair. (1978). Weathering: Poems and Translations. New York: E. P. Dutton.

SCHWARZ, Roberto. (1992). "Misplaced Ideas: Literature and Society in Late-Nineteenth-Century Brazil”. In: GLEDSON, John (ed.). Misplaced Ideas: Essays on Brazilian Culture. London \& New York: Verso, 19-32.

SLOTERDIJK, Peter. (2010). Rage and Time. A Psychopolitical Investigation. Tr. Mario Wenning. New York: Columbia University Press.

. (2014). "What does a human have that he can give away? An Interview with Peter Sloterdijk by Sjoerd van Tuinen". Tr. Sebastian Olma. In: BROUWER, Jake \& VAN TUININ, Sjoerd (eds.). Giving and Taking: Antidotes to a Culture of Greed. Rotterdam: V2 Publishing, 8-25.

VERANI, Hugo J. (1998). "José Emilio Pacheco: La voz complementaria”. Revista de Crítica Literaria Latinoamericana 24.47: 28192.

ZANETTI, Susana Emilce. (2010). "Traducciones, versiones y homenajes en la poesía de José Emilio Pacheco". Orbis Tertius 15.16: n.p. 
“Transfer” XIV: 1-2 (2019), pp. 73-99. ISSN: 1886-554

\begin{abstract}
:
José Emilio Pacheco affirms that poetry is made by the collective, anonymous effort of writers in every language, and his translation practice returns debts he feels he owes other writers, including his own translators. I use the theory of the gift developed by Marcel Mauss as a methodology to interrogate the translation networks Pacheco participated in and to highlight forms of translation that are reciprocal rather than unidirectional.
\end{abstract}

Key words: Literary translation, Reciprocity, Gift theory, José Emilio Pacheco, Mexican poetry

JOSÉ EMILIO PACHECO Y LA RECIPROCIDAD ENTRE CULTURAS LITERARIAS: LA TEORÍA DEL DON COMO METODOLOGÍA EN LOS ESTUDIOS DE TRADUCCIÓN

\title{
Resumen:
}

José Emilio Pacheco afirma que la poesía se realiza gracias al esfuerzo colectivo y anónimo de autores en todo idioma, y su práctica de traducción devuelve deudas que él siente que le deben a otros escritores, incluso sus propios traductores. Utilizo la teoría del don de Marcel Mauss como una metodología para interrogar las redes de la traducción en las que participó Pacheco y para resaltar las formas de traducción que son más recíprocas que unidireccionales.

Palabras clave: Traducción literaria; Reciprocidad; Teoría del don; José Emilio Pacheco; Poesía mexicana 